\title{
Fractionation of sulfur isotopes during heterogeneous oxidation of $\mathrm{SO}_{2}$ on sea salt aerosol: a new tool to investigate non-sea salt sulfate production in the marine boundary layer
}

\author{
E. Harris ${ }^{1}$, B. Sinha ${ }^{1,2}$, P. Hoppe ${ }^{1}$, S. Foley ${ }^{3}$, and S. Borrmann ${ }^{1}$ \\ ${ }^{1}$ Max-Planck-Institut für Chemie, Hahn-Meitner-Weg 1, 55128 Mainz, Germany \\ ${ }^{2}$ Department of Earth Sciences, Indian Institute for Science Education and Research IISER Mohali, Sector 81 SAS Nagar, \\ Manauli PO 140306, India \\ ${ }^{3}$ Earth System Science Research Centre, Institute for Geosciences, University of Mainz, Becherweg 21, 55128 Mainz, \\ Germany
}

Correspondence to: B. Sinha (baerbel.sinha@mpic.de)

Received: 8 January 2012 - Published in Atmos. Chem. Phys. Discuss.: 26 January 2012

Revised: 29 April 2012 - Accepted: 2 May 2012 - Published: 24 May 2012

\begin{abstract}
The oxidation of $\mathrm{SO}_{2}$ to sulfate on sea salt aerosols in the marine environment is highly important because of its effect on the size distribution of sulfate and the potential for new particle nucleation from $\mathrm{H}_{2} \mathrm{SO}_{4}(\mathrm{~g})$. However, models of the sulfur cycle are not currently able to account for the complex relationship between particle size, alkalinity, oxidation pathway and rate - which is critical as $\mathrm{SO}_{2}$ oxidation by $\mathrm{O}_{3}$ and $\mathrm{Cl}$ catalysis are limited by aerosol alkalinity, whereas oxidation by hypohalous acids and transition metal ions can continue at low $\mathrm{pH}$ once alkalinity is titrated. We have measured ${ }^{34} \mathrm{~S} /{ }^{32} \mathrm{~S}$ fractionation factors for $\mathrm{SO}_{2}$ oxidation in sea salt, pure water and $\mathrm{NaOCl}$ aerosol, as well as the $\mathrm{pH}$ dependency of fractionation.

Oxidation of $\mathrm{SO}_{2}$ by $\mathrm{NaOCl}$ aerosol was extremely efficient, with a reactive uptake coefficient of $\approx 0.5$, and produced sulfate that was enriched in ${ }^{32} \mathrm{~S}$ with $\alpha_{\mathrm{OCl}}=$ $0.9882 \pm 0.0036$ at $19^{\circ} \mathrm{C}$. Oxidation on sea salt aerosol was much less efficient than on $\mathrm{NaOCl}$ aerosol, suggesting alkalinity was already exhausted on the short timescale of the experiments. Measurements at $\mathrm{pH}=2.1$ and 7.2 were used to calculate fractionation factors for each step from $\mathrm{SO}_{2}(\mathrm{~g})$ $\rightarrow$ multiple steps $\rightarrow \mathrm{SO}_{3}^{2-}$. Oxidation on sea salt aerosol resulted in a lower fractionation factor than expected for oxidation of $\mathrm{SO}_{3}^{2-}$ by $\mathrm{O}_{3}\left(\alpha_{\text {seasalt }}=1.0124 \pm 0.0017\right.$ at $\left.19^{\circ} \mathrm{C}\right)$. Comparison of the lower fractionation during oxidation on sea salt aerosol to the fractionation factor for high $\mathrm{pH}$ oxidation shows $\mathrm{HOCl}$ contributed $29 \%$ of S(IV) oxidation on
\end{abstract}

sea salt in the short experimental timescale, highlighting the potential importance of hypohalous acids in the marine environment.

The sulfur isotope fractionation factors measured in this study allow differentiation between the alkalinity-limited pathways - oxidation by $\mathrm{O}_{3}$ and by $\mathrm{Cl}$ catalysis $\left(\alpha_{34}=\right.$ $1.0163 \pm 0.0018$ at $19^{\circ} \mathrm{C}$ in pure water or $1.0199 \pm 0.0024$ at $\mathrm{pH}=7.2$ ) - which favour the heavy isotope, and the alkalinity non-limited pathways - oxidation by transition metal catalysis $\left(\alpha_{34}=0.9905 \pm 0.0031\right.$ at $19^{\circ} \mathrm{C}$, Harris et al., 2012a) and by hypohalites $\left(\alpha_{34}=0.9882 \pm 0.0036\right.$ at $\left.19^{\circ} \mathrm{C}\right)-$ which favour the light isotope. In combination with field measurements of the oxygen and sulfur isotopic composition of $\mathrm{SO}_{2}$ and sulfate, the fractionation factors presented in this paper may be capable of constraining the relative importance of different oxidation pathways in the marine boundary layer.

\section{Introduction}

\subsection{The sulfur cycle in the marine boundary layer}

Sea-salt aerosol is the dominant form of aerosol in the marine environment. The potential for heterogeneous oxidation of $\mathrm{SO}_{2}$ on sea salt aerosol was first appreciated when ambient measurements showed that excess non-sea salt sulfate (nss-sulfate), particularly in coarse particles, could not be explained by homogeneous oxidation and in-cloud processes

Published by Copernicus Publications on behalf of the European Geosciences Union. 
alone (Sievering et al., 1991). Oxidation of $\mathrm{SO}_{2}$ in sea salt aerosol can reduce marine boundary layer (MBL) $\mathrm{SO}_{2}$ concentrations by up to $70 \%$, limiting gas phase production of $\mathrm{H}_{2} \mathrm{SO}_{4}$ and thus reducing or preventing new particle nucleation and CCN production (Chameides and Stelson, 1992; Katoshevski et al., 1999; Alexander et al., 2005). Sulfate production on sea salt aerosols shifts the sulfate size distribution towards coarse particles, leading to faster removal from the atmosphere, while having a relatively small effect on the $\mathrm{CCN}$ activity of the hygroscopic sea salt particles (Chameides and Stelson, 1992; Sievering et al., 1995; von Glasow, 2006). The effects of heterogeneous $\mathrm{SO}_{2}$ oxidation on the sulfur cycle in the MBL are particularly important due to the low albedo of the ocean and the strong climatic effect of marine clouds (von Glasow and Crutzen, 2004).

There are a number of different pathways by which $\mathrm{SO}_{2}$ can be oxidised on sea salt aerosol. Oxidation can occur directly on deliquescent aerosol, or in clouds when sea salt aerosol has acted as a CCN. Ozone is thought to be one of the most important oxidants in the MBL (Chameides and Stelson, 1992; Sievering et al., 1995). However, oxidation by ozone is strongly $\mathrm{pH}$ dependent and self-limiting as aerosol becomes acidified following sulfate production. The amount of sulfate generated by this pathway is therefore constrained by the alkalinity of the aerosol and the concentration of other gases, such as $\mathrm{HNO}_{3}$, which also titrate alkalinity (Chameides and Stelson, 1992; Zhang and Millero, 1991; von Glasow and Sander, 2001; Hoppel and Caffrey, 2005). Thus, $\mathrm{O}_{3}$ can only efficiently oxidise $\mathrm{SO}_{2}$ in sea salt aerosol in the first 10-20 min following emission, and oxidation by $\mathrm{O}_{3}$ occurs mainly in the lowest $50-100 \mathrm{~m}$ of the MBL which leads to rapid deposition of the sulfate produced (Chameides and Stelson, 1992; von Glasow and Sander, 2001; von Glasow and Crutzen, 2004).

Field measurements and laboratory studies commonly find that sulfate production is larger than would be expected from the neutralisation capacity of sea salt aerosol estimated from the alkalinity of bulk sea water (Sievering et al., 1999; Caffrey et al., 2001). Two explanations have been proposed: (i) oxidants other than $\mathrm{O}_{3}$ play a more important role than currently known, and (ii) the alkalinity of sea salt aerosol is larger than the alkalinity of bulk sea water. As sea salt aerosol form from bursting bubbles, they efficiently skim the surface microlayer which can have high alkalinity due to cations associated with organic molecules and biogenic skeletal fragments. This could provide up to 2.5 times additional alkalinity at typical marine sites, and $>200$ times more at especially favourable sites (Sievering et al., 1999, 2004). Following sea salt aerosol production, shifting of the carbonate equilibrium with evaporation causes the alkalinity of sea salt aerosol to be somewhat higher than bulk sea water, however this is insufficient to explain observed excess sulfate concentrations (Sievering et al., 1999). Laskin et al. (2003) proposed that interface reactions between $\mathrm{OH}(\mathrm{g})$ and surface chloride ions could also generate excess alkalinity in sea salt aerosol, however observations and models show that this pathway will account for $<1 \%$ extra sulfate production in the ambient environment (Sander et al., 2004; Keene and Pszenny, 2004; Alexander et al., 2005; von Glasow, 2006). As none of these mechanisms can adequately explain observations of sulfate production compared to alkalinity, it is likely an oxidant other than $\mathrm{O}_{3}$ is playing a significant role in the MBL.

Several reactions have been identified that may be as or more important than oxidation by $\mathrm{O}_{3}$ for sulfate production on sea salt aerosols in the marine boundary layer. Oxidation by $\mathrm{H}_{2} \mathrm{O}_{2}$ is believed to be unimportant and contributes $<4 \%$ of $n s s$-sulfate (Gurciullo et al., 1999). Transition metal ions and radicals such as $\mathrm{Fe}^{3+}, \mathrm{Br}$, $\cdot \mathrm{OH}$ and $\mathrm{Cl}$. can initiate radical chain reactions in which $\mathrm{SO}_{2}$ is oxidised by $\mathrm{O}_{2}$ (Zhang and Millero, 1991). In a chamber study with sea salt and pure $\mathrm{NaCl}$ aerosols, Hoppel et al. (2001) saw production of sulfate but no uptake of ozone. They proposed that oxidation catalysed by $\mathrm{Cl}$, which is second order in [S(IV)], is the dominant oxidation pathway in the MBL at high $\mathrm{SO}_{2}$ concentrations (Hoppel and Caffrey, 2005). However, oxidation by $\mathrm{Cl}$. catalysis, like oxidation by $\mathrm{O}_{3}$, is strongly $\mathrm{pH}$ dependent and limited by alkalinity. Oxidation by hypohalites and hypohalous acids $\left(\mathrm{HO}_{\mathrm{x}}\right)$ is not limited by alkalinity and may be the "missing" oxidation pathway in MBL models (von Glasow, 2006), although at low $\mathrm{pH} \mathrm{HOCl}$ and $\mathrm{HOBr}$ are converted to $\mathrm{Cl}_{2}, \mathrm{Br}_{2}$ or $\mathrm{BrCl}$ according to (IUPAC, 2009):

$\mathrm{HOCl}+\mathrm{H}^{+}+\mathrm{Cl}^{-} \rightarrow \mathrm{Cl}_{2}+\mathrm{H}_{2} \mathrm{O}$

Oxidation by $\mathrm{HOBr}$ is faster, however $\mathrm{HOCl}$ is likely to be the more important oxidant due to the relative abundances of $\mathrm{Br}$ and $\mathrm{Cl}$ (Troy and Margerum, 1991). von Glasow et al. (2002) modelled oxidation in the MBL and found that under almost all conditions, $\mathrm{HOCl}-$ not $\mathrm{O}_{3}$ - was the dominant oxidant for $\mathrm{SO}_{2}$. However, the $\mathrm{pH}$-dependent rate of halogen oxidation (eg. the rate of oxidation by $\mathrm{HOCl}$ compared to $\mathrm{OCl}^{-}$) is not well-constrained, although results suggest the oxidation rate will increase at lower $\mathrm{pH}$ (Yiin and Margerum, 1988; Shaka et al., 2007).

\subsection{Sulfur isotopes in the marine boundary layer}

The isotopic composition of sulfate in the environment reflects its sources, transport and chemistry, so stable isotopes of oxygen and sulfur in nss-sulfate can be especially useful to investigate the different oxidation pathways of $\mathrm{SO}_{2}$ in the MBL. Sulfur has four naturally-occurring stable isotopes: ${ }^{32} \mathrm{~S},{ }^{33} \mathrm{~S},{ }^{34} \mathrm{~S}$ and ${ }^{36} \mathrm{~S}$. The isotopic composition of a sulfur sample is described with the delta notation, which is the ratio of a heavy isotope to the most abundant isotope $\left({ }^{32} \mathrm{~S}\right)$ in the sample compared to V-CDT and expressed in permil:

$\delta^{x} \mathrm{~S}=\frac{\left(\frac{n\left({ }^{x} \mathrm{~S}\right)}{n\left({ }^{32} \mathrm{~S}\right)}\right)_{\mathrm{sample}}}{\left(\frac{n\left({ }^{x} \mathrm{~S}\right)}{\left.n{ }^{\left({ }^{2} \mathrm{~S}\right.}\right)}\right) \mathrm{V}-\mathrm{CDT}}-1$ 
where $n$ is the number of atoms, ${ }^{x} \mathrm{~S}$ is one of the heavy isotopes $\left({ }^{33} \mathrm{~S}\right.$ or $\left.{ }^{34} \mathrm{~S}\right)$ and V-CDT is the international sulfur isotope standard, Vienna Canyon Diablo Troilite, which has isotopic ratios of ${ }^{34} \mathrm{~S} /{ }^{32} \mathrm{~S}=0.044163$ and ${ }^{33} \mathrm{~S} /{ }^{32} \mathrm{~S}=0.007877$ (Ding et al., 2001). The kinetic isotope fractionation factor $(\alpha)$ is represented by the ratio of the heavy to the light isotope amount in the instantaneously formed product divided by the ratio in the reactant:

$\alpha_{34}=\frac{\left(\frac{\left.n{ }^{34} \mathrm{~S}\right)}{\left.n{ }^{(32} \mathrm{S}\right)}\right)_{\text {products }}}{\left(\frac{n{ }^{\left({ }^{4} \mathrm{~S}\right)}}{n\left({ }^{32} \mathrm{~S}\right)}\right)_{\text {reactants }}}$

Values of $\alpha_{34}$ can be characteristic for different reaction pathways and will therefore be useful to investigate the different oxidation pathways for $\mathrm{SO}_{2}$ in the marine environment.

The major sources of sulfate in the marine environment are isotopically distinct: sea salt sulfate has a $\delta^{34} \mathrm{~S}$ of $21 \%$, (Rees et al., 1978), marine biogenic $n s s$-sulfate has a $\delta^{34} \mathrm{~S}$ between 12 and 19\%o, (Calhoun et al., 1991; Sanusi et al., 2006), and anthropogenic sulfur emissions are often lighter, although there is significant variation between sources (Krouse et al., 1991; Nielsen et al., 1991). Sulfur isotope fractionation during $\mathrm{SO}_{2}$ oxidation has not usually been considered in analyses of MBL sulfate as the fractionation factors were not well known: $\alpha_{34}$ for gas phase oxidation of $\mathrm{SO}_{2}$ by $\cdot \mathrm{OH}$ radicals and for aqueous oxidation by $\mathrm{H}_{2} \mathrm{O}_{2}$ and $\mathrm{O}_{3}$ have recently been reported by Harris et al. (2012b), but the effect of heterogeneous processes on complex environmental substrates such as sea salt aerosol have not been measured. The results of Harris et al. (2012b) suggested isotopic fractionation during aqueous oxidation may increase at higher $\mathrm{pH}$, however the $\mathrm{pH}$ dependence was within the uncertainty of the measurements. Sea salt aerosols have much higher $\mathrm{pH}$ than typical cloud droplets, thus the $\mathrm{pH}$ dependence of isotopic fractionation will be particularly important in the MBL.

This study presents measurements of ${ }^{34} \mathrm{~S} /{ }^{32} \mathrm{~S}$ fractionation during $\mathrm{SO}_{2}$ oxidation in sea salt aerosol and $\mathrm{NaOCl}$ aerosol, and examines the role of $\mathrm{pH}$, ozone and irradiation in determining isotopic fractionation. These fractionation factors allow stable sulfur isotope ratio measurements to be used to investigate the contributions of different oxidation pathways to sulfate formation in the MBL, and may be particularly useful in combination with $\Delta^{17} \mathrm{O}$ measurements to determine the importance of alkalinity-limited pathways compared to alkalinity non-limited pathways.

\section{Methods}

The fractionation factors relevant to non-sea salt sulfate production in the MBL were considered with a series of experiments, in which $\mathrm{SO}_{2}$ with a known isotopic composition was oxidised to sulfate under various conditions. The sulfur isotopic composition of the residual $\mathrm{SO}_{2}$ and the product sulfate was measured with NanoSIMS to determine fractionation factors for $\mathrm{SO}_{2}$ oxidation during the major $\mathrm{MBL}$ oxidation pathways. Due to the relatively high $\mathrm{pH}$ of sea water and sea salt aerosol, compared to, for example, polluted cloud water, the first experiments presented consider fractionation during uptake of $\mathrm{SO}_{2}$ to the aqueous phase and the subsequent acidbase equilibria (Eqs. 7 to 10). Following this, fractionation factors specific to the various MBL oxidants are measured.

\subsection{Experimental set-up}

\subsubsection{Dependence of isotopic fractionation on $\mathrm{pH}$}

The $\mathrm{pH}$ dependence of isotopic fractionation during sulfate production by $\mathrm{H}_{2} \mathrm{O}_{2}$ was measured by oxidising $\mathrm{SO}_{2}$ in buffer solutions at high and low pHs. Two bubblers in series were used: the first bubbler contained buffer solution, along with $1 \% \mathrm{H}_{2} \mathrm{O}_{2}$ to oxidise $\mathrm{SO}_{2}$, and the second buffer contained $6 \% \mathrm{H}_{2} \mathrm{O}_{2}$ to collect residual $\mathrm{SO}_{2}$ as sulfate according to Harris et al. (2012b). $600 \mathrm{~cm}^{3} \mathrm{~min}^{-1}$ (at standard conditions of $T=273.15 \mathrm{~K}, P=1013.25 \mathrm{mbar}$ ) of $7 \mathrm{ppm} \mathrm{SO}_{2}$ gas (Linde AG) in synthetic air (Westfalen AG, 20.5\% $\mathrm{O}_{2}$ in $\mathrm{N}_{2}$ ) was passed through the bubblers for $8-9 \mathrm{~h}$. Two buffer solutions were used: The first buffer contained $0.1 \mathrm{M} \mathrm{H}_{3} \mathrm{PO}_{4}$ and $0.1 \mathrm{M} \mathrm{KH}_{2} \mathrm{PO}_{4}$ and had an initial $\mathrm{pH}$ of 2.1 , and the second buffer contained $0.1 \mathrm{M} \mathrm{KH}_{2} \mathrm{PO}_{4}$ and $0.1 \mathrm{M} \mathrm{K}_{2} \mathrm{HPO}_{4}$ and had an initial pH of 7.2 (Moore et al., 2005). The buffer concentration is $>150$ times in excess of the maximum acidity generated if all the $\mathrm{SO}_{2}$ was oxidised to sulfate, thus the buffer $\mathrm{pH}$ will not change significantly during the course of the experiment. The phosphate buffer system was chosen as it allows the $\mathrm{pH}$ to be held at two atmospherically-relevant values $(\mathrm{pH} \approx 2$ represents the lower boundary of typical cloud water $\mathrm{pH}$ and can be reached in sea salt aerosol in highly polluted areas, while the $\mathrm{pH}$ of sea water is 7.5-8.5; Sander and Crutzen, 1996; van Loon and Duffy, 2000) without the large change in the chemical environment that would be introduced by using different buffer systems for the two pHs.

Experiments at each of the two pHs were run in duplicate. Following the experiments, $\mathrm{BaCl}_{2}$ was added to the solutions from the bubblers to precipitate sulfate as $\mathrm{BaSO}_{4}$. The $\mathrm{BaSO}_{4}$ was collected on Nuclepore track-etch polycarbonate membrane filters (Whatman Ltd.) with $0.2 \mu \mathrm{m}$ pores, which had been coated with a $10 \mathrm{~nm}$ thick gold layer using a sputter coater (Bal-tec GmbH, Model SCD-050) prior to sample collection. The $\mathrm{BaSO}_{4}$ was then analysed in the NanoSIMS as described in Sect. 2.3. The reacted fraction was found from isotope mass balance between the products and the reactants:

$\delta^{34} \mathrm{~S}_{i}=f \delta^{34} \mathrm{~S}_{\mathrm{SO}_{2}}+(1-f) \delta^{34} \mathrm{~S}_{\text {sulfate }}$

where $f$ is the fraction of reactant $\left(\mathrm{SO}_{2}\right)$ remaining and $\delta^{34} \mathrm{~S}_{i}$, $\delta^{34} \mathrm{~S}_{\mathrm{SO}_{2}}$ and $\delta^{34} \mathrm{~S}_{\text {sulfate }}$ are the isotopic compositions of the initial $\mathrm{SO}_{2}$ gas, residual $\mathrm{SO}_{2}$ gas and product sulfate, respectively. The sulfate generated could not be determined gravimetrically due to interference from co-precipitated barium 


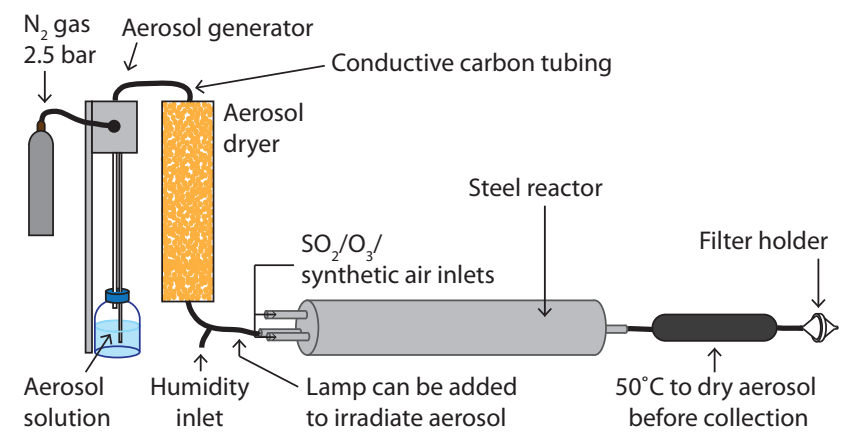

Fig. 1. Experimental set-up used to investigate isotopic fractionation during the oxidation of $\mathrm{SO}_{2}$ by sea salt aerosol.

phosphates. More than $5 \%$ of the $\mathrm{SO}_{2}$ was oxidised, thus the isotopic composition of the $\mathrm{SO}_{2}$ reservoir was affected by the reaction and the fractionation factors must be calculated according to the Rayleigh equations, which describe the relationship between accumulated product and reactant isotopic composition and reaction extent (Mariotti et al., 1981; Krouse and Grinenko, 1991):

$\alpha_{34}=\frac{\ln \frac{R_{\mathrm{r}}}{R_{0}}}{\ln f}+1$

$\alpha_{34}=\frac{\ln \left(1-\frac{R_{\mathrm{p}}}{R_{0}}(1-f)\right)}{\ln f}$

where $R_{0}, R_{\mathrm{r}}$ and $R_{\mathrm{p}}$ are the isotope ratios ${ }^{34} \mathrm{~S} /{ }^{32} \mathrm{~S}$ for the initial $\mathrm{SO}_{2}$ gas, the residual $\mathrm{SO}_{2}$ gas and the product sulfate respectively and $f$ is the fraction of reactant remaining following the reaction.

\subsubsection{Aqueous oxidation in droplets}

$\mathrm{SO}_{2}$ oxidation in aqueous aerosol was measured with three different solutions using the apparatus shown in Fig. 1: pure water (LiChrosolv chromatography water, Merck $\mathrm{GmbH}$ ), synthetic sea salt solution and $\mathrm{NaOCl}$ solution. The pure water solution was used to measure the background (when no oxidant was added) and to measure the fractionation factor from $\mathrm{SO}_{2}$ oxidation by $\mathrm{O}_{3}$. Commercial $\mathrm{NaOCl}$ (reagent grade, Sigma-Aldrich $\mathrm{GmbH}$ ) was diluted 1:20 to make the $\mathrm{NaOCl}$ solution with $0.5-0.75 \%$ active chlorine. The synthesic sea salt solution is described in the next section.

Aerosol was generated from the solutions with an atomizer built in-house: 2.5 bar $\mathrm{N}_{2}$ (Grade 6.0, Westfalen AG) expanded through a small orifice to form a high velocity gas jet which atomized the liquid as it was sucked up from a reservoir. Only fine spray leaves the atomizer as large droplets are removed by impaction on the wall facing the jet. PFA fittings were used for all connections. The reactor was made of steel and carbon-coated tubing was used to minimise aerosol loss through electrostatic attraction. The size and volume distributions measured with an optical particle counter (OPC;
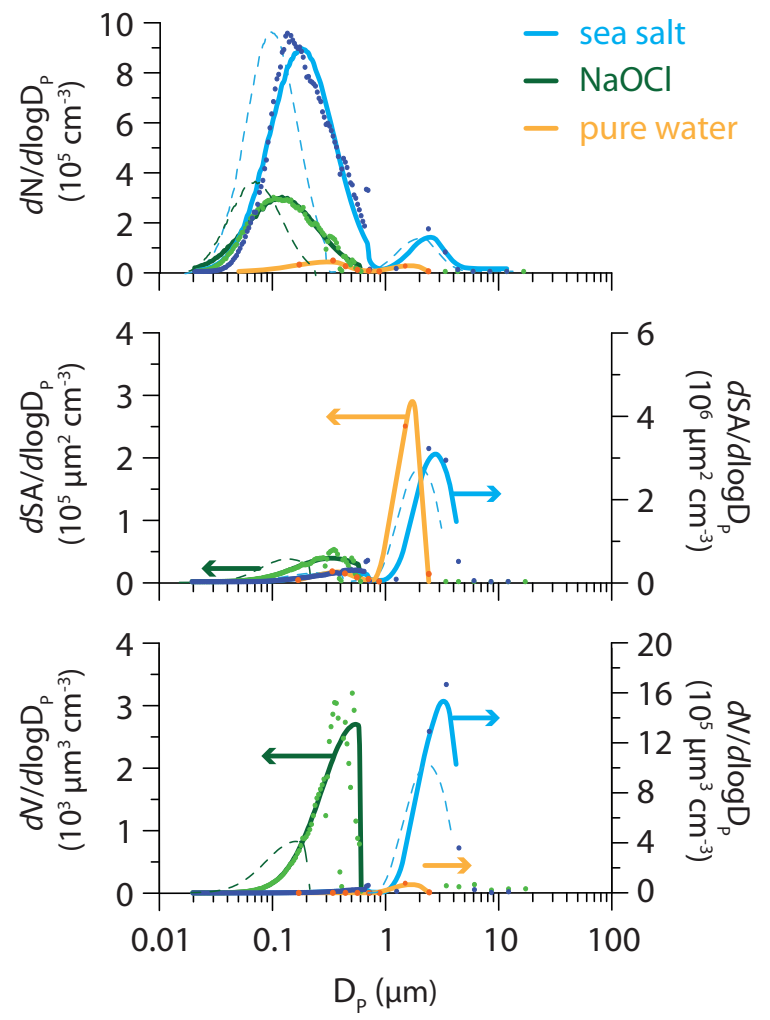

Fig. 2. Size, surface area and volume distributions of aerosol produced from various solutions: synthetic sea salt solution is shown in blue, water is shown in orange and $\mathrm{NaOCl}$ solution is shown in green. Individual points represent measurements while solid lines show fits to a log-normal distribution before the aerosol was dried. The log-normal fit following the dryer is shown as a dashed line. The axis on which each aerosol type is plotted is indicated with arrows.

Grimm Portable Aerosol Spectrometer, Model 1.108) and a scanning mobility particle sizer (SMPS; TSI Electrostatic Classifier, Model 3080 coupled to TSI Ultrafine CPC, Model 3025A) are shown in Fig. 2. The aerosol was passed through a drier containing silica gel, which reduced the volume of aerosol by $20 \%$ for the sea salt solution and $\approx 90 \%$ for pure water and $\mathrm{NaOCl}$ solution, and shifted the size distribution towards smaller particles.

$50 \mathrm{~cm}^{3} \mathrm{~min}^{-1}$ of $\mathrm{SO}_{2}$ gas (Linde $\mathrm{AG},(102 \pm 2) \mathrm{ppm}$ in synthetic air) was added to the reactor along with $300 \mathrm{~cm}^{3} \mathrm{~min}^{-1}$ of aerosol in $\mathrm{N}_{2}, 100 \mathrm{~cm}^{3} \mathrm{~min}^{-1}$ of humidified synthetic air (Westfalen AG, $20.5 \% \mathrm{O}_{2}$ in $\mathrm{N}_{2}$ ), and $100 \mathrm{~cm}^{3} \mathrm{~min}^{-1}$ of extra synthetic air, giving a total flow of $550 \mathrm{~cm}^{3} \mathrm{~min}^{-1}$, a relative humidity of $\approx 35 \%$, and an $\mathrm{SO}_{2}$ concentration of $9 \mathrm{ppm}$. The reactor was $55 \mathrm{~cm}$ long and had a diameter of $8 \mathrm{~cm}$, resulting in a residence time for the aerosol of 302 seconds. The reacted aerosol was collected on a Nuclepore track-etch polycarbonate membrane filter (Whatman Ltd.) with $0.2 \mu \mathrm{m}$ pores. The filter was changed every $1.5-3.5 \mathrm{~h}$ depending on the accumulation of aerosol. 
Table 1. Experiments to investigate isotopic fractionation during oxidation of $\mathrm{SO}_{2}$ on sea salt aerosol. ${ }^{1} \mathrm{SO}_{2}$ flow was replaced with synthetic air to measure sulfate in sea salt samples that had not been exposed to $\mathrm{SO}_{2} \cdot{ }^{2}$ Collected directly on a gold-coated filter and analysed in the NanoSIMS without extracting to $\mathrm{BaSO}_{4}$.

\begin{tabular}{|c|c|c|c|c|c|}
\hline Abb. & Solution & $\mathrm{O}_{3}$ & Irradiated & Run & $\begin{array}{l}\text { Length } \\
\text { (hours) }\end{array}$ \\
\hline \multirow{3}{*}{$\begin{array}{c}\text { waterA } \\
\text { waterAO3 }\end{array}$} & pure water & no & no & 1 & 7.8 \\
\hline & pure water & yes & no & 1 & 7.8 \\
\hline & & & & 2 & 8.5 \\
\hline \multirow[t]{2}{*}{$\mathrm{OCl}$} & $\mathrm{NaOCl}$ & no & no & 1 & 7.6 \\
\hline & & & & 2 & 7.6 \\
\hline \multirow[t]{2}{*}{ OClirr } & $\mathrm{NaOCl}$ & no & yes & 1 & 7.7 \\
\hline & & & & 2 & 7.0 \\
\hline \multirow[t]{3}{*}{ ssaltblank $^{1}$} & sea salt & no & no & 1 & 7.0 \\
\hline & & & & 2 & 3.2 \\
\hline & & & & 3 & 8.6 \\
\hline \multirow[t]{2}{*}{ ssalt } & sea salt & no & no & 1 & 7.8 \\
\hline & & & & 2 & 8 \\
\hline \multirow[t]{2}{*}{ ssaltO3 } & sea salt & yes & no & 1 & 8 \\
\hline & & & & 2 & 7.9 \\
\hline \multirow[t]{2}{*}{ ssaltO3direct $^{2}$} & sea salt & yes & no & 1 & 0.3 \\
\hline & & & & 2 & 0.3 \\
\hline \multirow[t]{2}{*}{ ssaltirr } & sea salt & no & yes & 1 & 10.2 \\
\hline & & & & 2 & 8.4 \\
\hline \multirow[t]{2}{*}{ ssaltirrO3 } & sea salt & yes & yes & 1 & 7.0 \\
\hline & & & & 2 & 7.8 \\
\hline
\end{tabular}

Following each experiment, the filters were extracted for $30 \mathrm{~min}$ in an ultrasonic bath, rinsed, and extracted for another $30 \mathrm{~min}$. The rinses and extracts were collected and $\mathrm{BaCl}_{2}$ was added to precipitate sulfate as $\mathrm{BaSO}_{4}$, which was then collected by filtration on to gold-coated Nuclepore filters. One sample of sea salt aerosol $+\mathrm{O}_{3}$ ( $\mathrm{ssaltO}_{3}$, see following paragraph) was collected directly on to a gold-coated Nuclepore filter and analysed as untreated sea salt + sulfate particles, as this more closely resembles sea salt sampling in field campaigns. This sample will be referred to as "ssaltO3direct". However, the concentration of sea salt in the droplets was so high that this sample could only be collected for $<20 \mathrm{~min}$ before the filter was too heavily loaded for NanoSIMS analysis.

The aerosol was subjected to a number of different conditions, to investigate the effect of various parameters on $\mathrm{SO}_{2}$ oxidation. $20 \mathrm{ppm}$ ozone was added by passing the $100 \mathrm{~cm}^{3} \mathrm{~min}^{-1}$ extra synthetic air flow over a low-pressure mercury vapour lamp (Jelight Company Inc., USA) in 6 experiments. The aerosol itself was passed over the high-energy UV light from the low-pressure mercury vapour lamp before entering the reactor in 8 experiments, to investigate the effect of $\mathrm{OH}$ radicals and other compounds resulting from irradiation. This was done before mixing with synthetic air and $\mathrm{SO}_{2}$ to avoid $\mathrm{O}_{3}$ production and $\mathrm{SO}_{2}$ photolysis, and as close to the reactor inlet as possible to minimise loss of radicals. All experiments are summarised in Table 1 along with abbreviations that will be used throughout this paper.

\subsubsection{Seawater preparation}

Synthetic sea salt was prepared according to Kester et al. (1967) and Millero (1974). However, $\mathrm{Na}_{2} \mathrm{SO}_{4}$ was replaced with $\mathrm{NaCl}$ to avoid background sulfate in the solution, which would complicate measurements of the isotopic fractionation during sulfate production. The compounds used to prepare the sea salt solution along with their contributions to background sulfate are shown in Table 2. The sea salt stock solution, as shown in the table, was four times more concentrated than actual sea water. Its $\mathrm{pH}$ was measured to be 7.7 and the alkalinity (approximated as $0.005\left[\mathrm{Na}^{+}\right]$; Sievering et al., 2004; Chameides and Stelson, 1992) was $10 \mathrm{mmol} \mathrm{l}^{-1}$. When used for aerosol generation, this was diluted to be twice as concentrated as normal sea water to represent the increased concentration of atmospheric sea salt aerosol compared to sea water due to evaporation and other processes occurring during and after emission (Sievering et al., 1999). Following drying the aerosol will be $\approx 3$ times more concentrated than sea water. Sea salt aerosols are commonly up to ten times more concentrated than sea water (Sander and Crutzen, 1996), however this high concentration could not be achieved in the system as precipitating salts then caused small orifices to clog very quickly.

\subsection{SEM analysis}

A LEO 1530 field emission scanning electron microscope (SEM) with an Oxford Instruments ultra-thin-window energy-dispersive $\mathrm{x}$-ray detector (EDX) was used to quantify the sulfate produced in the droplet experiments. The SEM was operated with an accelerating voltage of $10 \mathrm{keV}$, a $60 \mu \mathrm{m}$ aperture and a working distance of $9.6 \mathrm{~mm}$. 'High current mode' was used to increase the EDX signal and improve elemental sensitivity. The SEM was run in automatic mode and took 400 evenly-spaced images of each filter at 19500x magnification. The EDX spectrum was measured with a $1 \mathrm{~s}$ integration time at 25 points on a $5 \times 5$ grid for each image, leading to 10000 EDX measurements across each filter. The quantity of sulfate on each filter was then determined by estimating the background from both the Gaussian distribution of the gold signal and the quartile method, as described in Harris et al. (2012b). This quantification method is ideal for NanoSIMS studies, as quantification is achieved without extra sample treatment and the limit of detection is very low. The precision is fairly low $(\approx 40 \%$, decreasing with increasing $\mathrm{BaSO}_{4}$ quantity due to Poisson statistics) and the method is not ideal for samples with a large amount of $\mathrm{BaSO}_{4}$ due to the possibility of the sample flaking off the filter during mounting. The precision of quantification did not affect the calculated isotopic fractionation factors as the SEM 
Table 2. Compounds used to prepare a four-times concentrated sulfate-free synthetic sea salt solution. * Prepared solution was four times more concentrated than actual sea salt, so here it is divided by four to facilitate comparison with actual concentrations. ${ }^{\#}$ From Millero (1974).

\begin{tabular}{crcrr|ccc}
\hline & $\begin{array}{r}\text { Amount } \\
\mathrm{g} \mathrm{kg}^{-1}\end{array}$ & Supplier & $\begin{array}{r}\text { max. } w_{\mathrm{SO}_{4}} \\
\left(\mathrm{mg} \mathrm{kg}^{-1} \text { dry }\right)\end{array}$ & $\begin{array}{r}m_{\mathrm{SO}_{4} \text { contributed }} \\
(\mathrm{mmol} / \mathrm{kg} \text { soln })\end{array}$ & Ion & $\begin{array}{c}w_{\text {synthetic }} \\
\mathrm{g} \mathrm{kg}^{-1}\end{array}$ & $\begin{array}{c}w_{\text {actual }} \\
\mathrm{g} \mathrm{kg}^{-1}\end{array}$ \\
\hline $\mathrm{NaCl}$ & 111.75 & Applichem & 10 & 12 & $\mathrm{Na}^{+}$ & 11.0 & 10.8 \\
$\mathrm{Na}_{2} \mathrm{SO}_{4}$ & 0 & & & & $\mathrm{Cl}^{-}$ & 21.8 & 19.4 \\
$\mathrm{KCl}$ & 2.79 & VWR & 10 & 0.29 & $\mathrm{~K}^{+}$ & 0.399 & 0.399 \\
$\mathrm{KBr}$ & 0.40 & Applichem & 50 & 0.21 & $\mathrm{Br}^{-}$ & 0.0674 & 0.0674 \\
$\mathrm{NaF}$ & 0.012 & Applichem & 100 & 0.012 & $\mathrm{~F}^{-}$ & 0.0013 & 0.0013 \\
$\mathrm{NaHCO}_{3}$ & 0.62 & Sigma-Aldrich & 30 & 0.19 & $\mathrm{HCO}_{3}^{-}$ & 0.113 & 0.112 \\
$\mathrm{H}_{3} \mathrm{BO}_{3}$ & 0.11 & Applichem & 50 & 0.056 & $\mathrm{H}_{3} \mathrm{BO}_{3}$ & 0.0269 & 0.0269 \\
$\mathrm{MgCl}_{2} \cdot 6 \mathrm{H}_{2} \mathrm{O}$ & 43.29 & Fisher & 9.92 & 4.5 & $\mathrm{Mg}^{2+}$ & 1.29 & 1.29 \\
$\mathrm{CaCl}_{2} \cdot 2 \mathrm{H}_{2} \mathrm{O}$ & 6.04 & Sigma-Aldrich & 100 & 6.3 & $\mathrm{Ca}^{2+}$ & 0.412 & 0.412 \\
$\mathrm{SrCl}_{2} \cdot 6 \mathrm{H}_{2} \mathrm{O}$ & 0.10 & Sigma-Aldrich & 10 & 0.010 & $\mathrm{Sr}^{2+}$ & 0.0079 & 0.0079 \\
\hline & & & Total sulfate & 23 & $\mathrm{SO}_{4}^{2-}$ & 0.0006 & 2.712 \\
\hline
\end{tabular}

quantification was only used to estimate reactive uptake coefficients in the different aerosol types.

\subsection{NanoSIMS analysis}

The sulfur isotopic composition was determined with the Cameca NanoSIMS 50 ion probe at the Max Planck Institute for Chemistry in Mainz (Hoppe, 2006; Groener and Hoppe, 2006). The NanoSIMS 50 has high lateral resolution $(<100 \mathrm{~nm})$ and high sensitivity and can simultaneously measure up to five different masses through a multicollection system, allowing high precision analysis of the small sample quantities required for this study. The use of this instrument to analyse sulfur isotope ratios is described in detail elsewhere (Winterholler et al., 2006, 2008) so only a brief description will be given here.

$\mathrm{BaSO}_{4}$ is analysed directly without further processing after it is collected on gold-coated filters as described in Sect. 2.1. The ssaltO3direct sample and all other samples with a particularly high $\mathrm{BaSO}_{4}$ loading were gold-coated on top of the sample before NanoSIMS analysis to prevent excessive charging. The analysis conditions were the same as those described in Harris et al. (2012b). To correct for instrumental mass fractionation (IMF) in ssdirectO ${ }_{3}$, which consisted of $\mathrm{NaSO}_{4}$ rather than $\mathrm{BaSO}_{4}$, the IMF correction for $\mathrm{NaSO}_{4}$ relative to $\mathrm{BaSO}_{4}$ from Winterholler et al. (2008) was used, along with an $\mathrm{Na}_{2} \mathrm{SO}_{4}$ standard (VWR $\mathrm{GmbH}$ ) for control. The reported results for each experiment are the average of at least 5 measurement spots weighted according to the counting statistical error, as described in Harris et al. (2012b).

\section{Results and discussion}

\subsection{Background and interferences}

The background sulfate production in the absence of an added oxidant was measured by running the reactor with MilliQ water and $\mathrm{SO}_{2}$. The SEM measurements showed that $(0.7 \pm 0.7) \mathrm{nmol} \mathrm{h}^{-1}$ of sulfate was generated, with a $\delta^{34} \mathrm{~S}$ of $(17.0 \pm 4.7) \%$. This is consistent with measurements of $\mathrm{SO}_{2}$ aqueous oxidation $\left(\delta^{34} \mathrm{~S}=(15.1 \pm 1.3) \%\right.$ ) and of sulfate production from $\mathrm{SO}_{2}$ on glass walls in the absence of an added oxidant $\left(\delta^{34} \mathrm{~S}=(13.0 \pm 1.5) \%\right.$ \% (Harris et al., 2012b), showing that the background sulfate is produced from aqueous oxidation by oxidising impurities in the MilliQ water and/or on the reactor walls. The background contributes $<13 \%$ of sulfate to all samples and a correction was made to take this into account when calculating the fractionation factors.

Background sulfate will also be present in the sea salt aerosol experiments from the sea salt mixture itself. The predicted background of sulfate was $<9.7 \times 10^{-6} \mathrm{nmol} \mathrm{h}^{-1}$, calculated from the maximum impurity levels in the salts used for preparation and the total volume of aerosol measured by OPC and SMPS. This was tested by running the reactor with sea salt aerosol but no $\mathrm{SO}_{2} \cdot(0.01 \pm 0.01) \mathrm{nmol} \mathrm{h}^{-1}$ of sulfate was measured on the sea salt blank filters in the SEM. The SEM value may be higher than the actual quantity due to the extremely small amount of sulfate present and the difficulty of separating the gold and sulfur peaks in the EDX (see Harris et al., 2012b). The blank filters were also examined in the NanoSIMS. Four (two per filter) $40 \times 40 \mu \mathrm{m}$ images integrating the signal over $\approx 15 \mathrm{~min}$ were taken to test if any sulfate particles could be seen. Only one sulfate particle was noticeable, on a total filter area of $9600 \mu \mathrm{m}^{2}$. This results in a blank of 1 particle in $>900$ particles. Such a blank can be caused by deposition of laboratory dust or by dislodging particles from another filter during handling of the sample. $5 \times 5 \mu \mathrm{m}$ isotope 
Table 3. Fractionation factors for $\mathrm{SO}_{2}$ uptake and oxidation at different $\mathrm{pH}$ values. Values at $\mathrm{pH}=2.1$ and 7.2 were measured at $19^{\circ} \mathrm{C}$ during the aqueous oxidation of $\mathrm{SO}_{2}$ in $1 \% \mathrm{H}_{2} \mathrm{O}_{2}$ at two different $\mathrm{pHs}$. The fractionation factors are the average of duplicate experiments and the uncertainty is the $1 \sigma$ error in the measurements. ${ }^{*} \mathrm{pH}=4$ was measured by Egiazarov et al. (1971) and does not include a terminating oxidation reaction.

\begin{tabular}{rrrrrr}
\hline $\mathrm{pH}$ & $f\left(\mathrm{H}_{2} \mathrm{SO}_{3}\right)$ & $f\left(\mathrm{HSO}_{3}^{-}\right)$ & $f\left(\mathrm{SO}_{3}^{2-}\right)$ & $\alpha_{34}$ & $1 \sigma$ \\
\hline 2.1 & 0.46 & 0.54 & 0 & 1.0154 & 0.0037 \\
$4^{*}$ & 0 & 1 & 0 & 1.0173 & 0.0003 \\
7.2 & 0 & 0.5 & 0.5 & 1.0199 & 0.0024 \\
\hline
\end{tabular}

analyses were taken to quantify the ${ }^{32} \mathrm{~S}$ signal from the salt on the filter. The average count rate was $(61 \pm 61)$ counts per second for the 9 analyses. This is not significantly different from the background count rate of untreated the Nuclepore filters (32 counts per second). Thus, the background sulfate contributed by the sea salt solution is insignificant and does not need to be corrected for in the following analyses.

The ssaltO3direct sample was measured to test if extra fractionation was introduced by extracting the collected sulfate and precipitating as $\mathrm{BaSO}_{4}$. The IMF for $\mathrm{Na}_{2} \mathrm{SO}_{4}$ was measured to test that different instrumental conditions had not affected the correction for $\mathrm{NaSO}_{4}$ relative to $\mathrm{BaSO}_{4}$; the measured relative IMF agreed with the value quoted in Winterholler et al. (2008). The value in Winterholler et al. (2008) was used for the correction as it has a smaller uncertainty than the value measured in the present study. The fractionation measured for ssaltO3direct agreed with the sea salt samples that were extracted and analysed as $\mathrm{BaSO}_{4}$, with measured fractionation factors of $\alpha_{34}=1.014 \pm 0.011$ and $\alpha_{34}=1.0137 \pm 0.0035$, respectively. This shows that no information is lost and no isotopic fractionation is introduced by extracting and precipitating the sulfate as $\mathrm{BaSO}_{4}$ for analysis. The counting statistical error for ssaltO3direct was very high as the sample could only be collected for $<20$ minutes before the filter loading was too high for NanoSIMS analysis ( $>5 \mu$ m-thick cover over whole filter).

\subsection{Dependence of isotopic fractionation on pH during aqueous oxidation by $\mathrm{H}_{2} \mathrm{O}_{2}$}

The fractionation factors measured at high and low $\mathrm{pH}$ are shown in Table 3. These measurements can be used to assign the fractionation to each step of $\mathrm{SO}_{2}$ hydrolysis and deprotonation:

$$
\begin{aligned}
& \mathrm{SO}_{2}(\mathrm{~g}) \rightleftharpoons \mathrm{SO}_{2}(\mathrm{aq}) \\
& \mathrm{SO}_{2}(\mathrm{aq})+\mathrm{H}_{2} \mathrm{O} \rightleftharpoons \mathrm{H}_{2} \mathrm{SO}_{3} \\
& \mathrm{H}_{2} \mathrm{SO}_{3} \rightleftharpoons \mathrm{HSO}_{3}^{-}+\mathrm{H}^{+} \\
& \mathrm{HSO}_{3}^{-} \rightleftharpoons \mathrm{SO}_{3}^{2-}+\mathrm{H}^{+}
\end{aligned}
$$

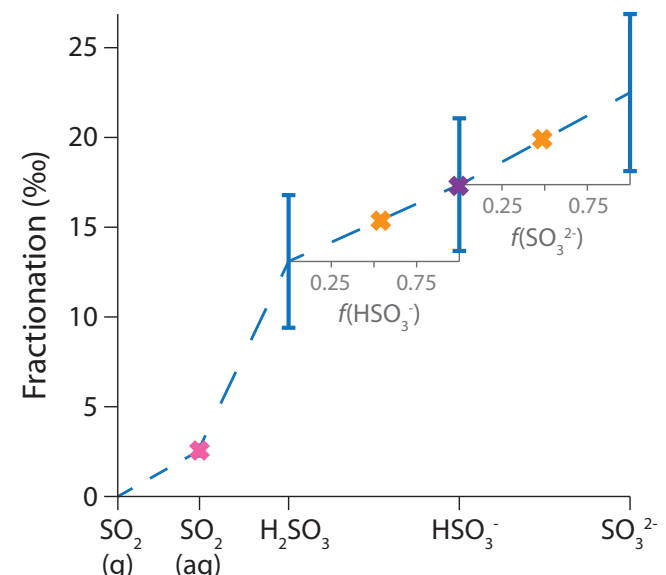

Fig. 3. Fractionation of ${ }^{34} \mathrm{~S} /{ }^{32} \mathrm{~S}$ at the different stages of $\mathrm{SO}_{2}(\mathrm{~g}) \rightarrow$ $\mathrm{SO}_{3}^{2-}$ (aq) expressed as $\left(\left(\alpha_{34}-1\right) \times 1000\right)$. The blue line and error bars show the cumulative change in $\delta^{34} \mathrm{~S}$ as the reactions proceed. The crosses show measurements: yellow crosses are results from this paper, the pink cross is from Chmielewski et al. (2002) and the purple cross is from Egiazarov et al. (1971). All values are shown for $18-19^{\circ} \mathrm{C}$.

Reaction (9) has a $\mathrm{pK}_{a}$ of 1.77 and Reaction (10) has a $\mathrm{pK}_{a}$ of 7.19 (Moore et al., 2005). Chmielewski et al. (2002) measured the fractionation factor for phase change (Eq. 7) to be $\alpha_{\text {phase }}=1.00256 \pm 0.00024$ at $18^{\circ} \mathrm{C}$. The fractionation factors for hydration (Eq. 8) and the first proton loss (Eq. 9) can be found by plotting the fractionation factors at $\mathrm{pH}=2.1$ and $\mathrm{pH}=4$ (Eriksen, 1972) against the fraction of $\mathrm{HSO}_{3}^{-}$: The intercept at $f\left(\mathrm{HSO}_{3}^{-}\right)=0$ gives the fractionation factor for hydration as $\alpha_{\text {hydration }}=1.0105 \pm 0.0037$, and the increase in fractionation at $f\left(\mathrm{HSO}_{3}^{-}\right)=1$ gives the fractionation factor for the first proton loss as $\alpha_{K_{a_{1}}}=1.0042 \pm 0.0037$ (Fig. 3). A plot of the fractionation factors at $\mathrm{pH}=4$ and $\mathrm{pH}=7.2$ against the fraction of $\mathrm{SO}_{3}^{2-}$ can be used to find the fractionation factor for the second proton loss (Eq. 10) at the intercept where $f\left(\mathrm{SO}_{3}^{2-}\right)=1: \alpha_{K_{a_{2}}}=1.0052 \pm 0.0044$. This analysis assumes fractionation is due to equilibration between the different S(IV) species and not due to fractionation during the oxidation of each S(IV) species to sulfate; this is a reasonable assumption as previous results suggest the terminating oxidation has a minimal isotopic effect (Harris et al., 2012b). The measurements and fractionations introduced at each step from $\mathrm{SO}_{2}(\mathrm{~g})$ to $\mathrm{SO}_{3}^{2-}$ are summarised in Fig. 3 .

\subsection{Sulfate production rate during aqueous oxidation in droplets}

The quantity of sulfate produced from $9 \mathrm{ppm} \quad \mathrm{SO}_{2}$ $\left(11.5 \mu \mathrm{mol} \mathrm{h}^{-1}\right)$ in the different droplet experiments is shown in Fig. 4. The amount of sulfate generated in sea salt aerosol in the presence and absence of $\mathrm{O}_{3}$ is not significantly different. Quantification for ssaltirr has a larger error than the other ssalt experiments due to tearing during mounting of the 

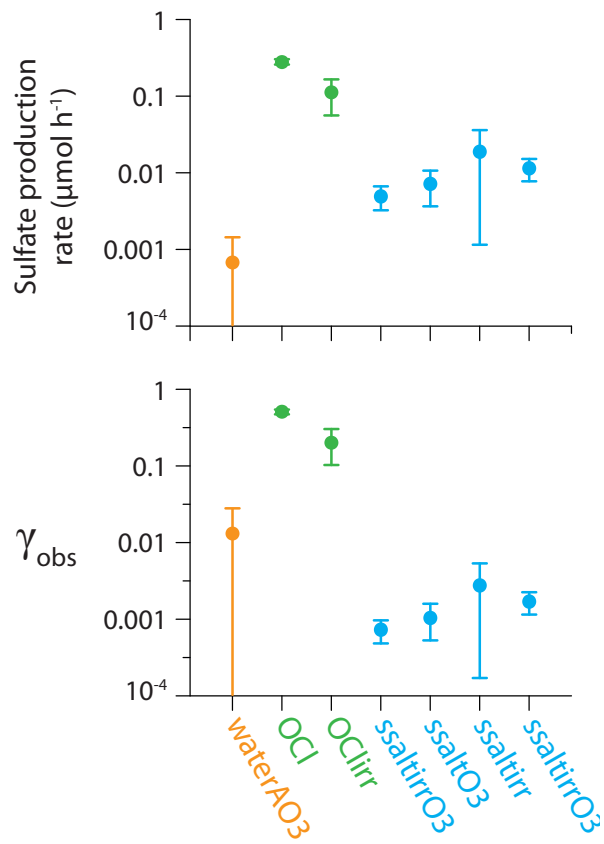

Fig. 4. Rates of sulfate production and reactive uptake coefficients for $\mathrm{SO}_{2}(\mathrm{~g})$ oxidation in different aerosol types subject to various experimental parameters (abbreviations are defined in Table 1).

filter for SEM analysis, which could obscure differences in production rate. However, there is also no significant different between sulfate production rates for ssalt, ssaltO3 and ssaltirrO3, which have smaller errors. Sulfate generation from oxidation by $\mathrm{O}_{3}$ is limited by alkalinity, so this suggests that either (i) another pathway also limited by alkalinity is fast enough to titrate alkalinity completely in the absence of $\mathrm{O}_{3}$, or (ii) $\mathrm{O}_{3}$ has no significant role in oxidation in sea salt aerosol, even when it is present in the reactor air. Hoppel et al. (2001) conducted chamber oxidation experiments for $\mathrm{SO}_{2}$ in sea salt aerosol and found oxidation was dominated by Cl-catalysis: the "ZM mechanism" (Zhang and Millero, 1991). This pathway is alkalinity-limited and favoured at high $\mathrm{SO}_{2}$ concentrations (Hoppel and Caffrey, 2005), and is the most likely oxidation pathway to be acting complementary to $\mathrm{O}_{3}$ in the sea salt experiments.

Rough estimates of the uptake coefficients for the different experiments were made. The observed reactive uptake coefficient $\gamma_{\text {obs }}$ for sulfate production represents a combination of mass transfer, accommodation and reaction limitations. It is approximated at low conversion to product according to (Jayne et al., 1990):

$\gamma_{\mathrm{obs}}=\frac{4 F_{\mathrm{g}}}{\bar{c} A} \frac{\Delta n}{n}$

where $F_{\mathrm{g}}$ is the carrier gas flow rate $\left(\mathrm{cm}^{3} \mathrm{~s}^{-1}\right), \bar{c}$ is the mean thermal velocity $\left(\mathrm{cm} \mathrm{s}^{-1} ; \sqrt{\frac{3 k_{B} \mathrm{~T}}{m}}\right), \mathrm{A}$ is the total droplet surface area $\left(\mathrm{cm}^{2}\right)$ and $\frac{\Delta n}{n}$ is the reduction in gas concentration.
Table 4. Fractionation factors for the uptake and oxidation of $\mathrm{SO}_{2}$ by droplets of pure water, sea salt aerosol and $\mathrm{NaOCl}$ aerosol (abbreviations are defined in Table 1). Values in bold are the averages for a particular aerosol type; for the oxidation of $\mathrm{SO}_{2}$ in pure water aerosol by $\mathrm{O}_{3}$, the present value is averaged with previous measurements. * from Harris et al. (2012b). $n$ is the number of measurements and $1 \sigma$ is the error of the measurements.

\begin{tabular}{lrrrrr}
\hline & $n$ & $\alpha_{34}$ & $1 \sigma$ & $\alpha_{33}$ & $1 \sigma$ \\
\hline waterAO3 & 13 & 1.0157 & 0.0031 & 1.0022 & 0.0034 \\
waterAO3 $^{*}$ & & 1.0174 & 0.0019 & 1.0057 & 0.0022 \\
water $+\boldsymbol{O}_{3}$ & & $\mathbf{1 . 0 1 6 3}$ & 0.0018 & $\mathbf{1 . 0 1 1 7}$ & 0.0207 \\
\hline OCl & 18 & 0.9872 & 0.0049 & 0.9930 & 0.0053 \\
OClirr & 15 & 0.9893 & 0.0054 & 0.9956 & 0.0045 \\
NaOCl & & $\mathbf{0 . 9 8 8 2}$ & 0.0036 & $\mathbf{0 . 9 9 4 6}$ & 0.0034 \\
\hline ssalt & 16 & 1.0137 & 0.0029 & 1.0087 & 0.0055 \\
ssaltO3 & 18 & 1.0136 & 0.0037 & 1.0063 & 0.0033 \\
ssaltirr & 14 & 1.0147 & 0.0046 & 1.0068 & 0.0052 \\
ssaltirrO3 & 15 & 1.0089 & 0.0032 & 1.0043 & 0.0036 \\
sea salt & & $\mathbf{1 . 0 1 2 4}$ & 0.0017 & $\mathbf{1 . 0 0 6 1}$ & 0.0020 \\
\hline
\end{tabular}

The reduction in $\mathrm{SO}_{2}$ was approximated as the sulfate production rate and therefore does not consider S(IV) (aq) that was taken up but not oxidised.

The uptake coefficients for $\mathrm{NaOCl}$ aerosol are very high, and significantly higher without irradiation $\left(\gamma_{\mathrm{obs}}=0.49 \pm\right.$ 0.04 and $0.20 \pm 0.10$ without and with irradiation, respectively). Oxidation of sulfite by $\mathrm{HOCl}$ proceeds via nucleophilic attack of $\mathrm{SO}_{3}^{2-}$ (formed via Eq. 10) on $\mathrm{HOCl}$, which results in $\mathrm{Cl}^{+}$transfer to form $\mathrm{ClSO}_{3}^{-}$(Yiin and Margerum, 1988). Hydrolysis of chlorosulfuric acid to form sulfate, $\mathrm{H}^{+}$ and $\mathrm{Cl}^{-}$is the rate-limiting step, thus the aerosol will not be acidified as rapidly as with other oxidation mechanisms (Yiin and Margerum, 1988; Fogelman et al., 1989; Troy and Margerum, 1991), which may partially explain the very high reactive uptake coefficient. Irradiation could speed up the hydrolysis of $\mathrm{ClSO}_{3}^{-}$, decreasing the reactive uptake coefficient.

The values of $\gamma_{\text {obs }}$ measured for the sea salt aerosols (average $\gamma_{\text {obs }}=0.0009 \pm 0.0002$ ) are much lower than those for $\mathrm{OCl}$ droplets, and also lower than previously reported values: Jayne et al. (1990) measured $\gamma=0.028 \pm 0.005$ at $\mathrm{pH}$ 6-8 and Gebel et al. (2000) measured an initial uptake coefficient of $\gamma_{i}=0.09$ which decreased rapidly with a $t^{-1 / 2}$ dependence. The low reactive uptake coefficients in this study are due to fast exhaustion of the alkalinity in the aerosols followed by much slower uptake in the acidified aerosols, resulting in low $\gamma_{\mathrm{obs}}$ for the overall experiment. Similar behaviour of the $\mathrm{SO}_{2}$ uptake coefficient for sea salt aerosol was seen by Gebel et al. (2000). The values of $\gamma_{\text {obs }}$ measured for the irradiated sea salt experiments are slightly higher than without irradiation, although the difference is within the experimental error. This suggests a small production of alkalinity from $\mathrm{OH}$ radicals due to reactions such as those described 


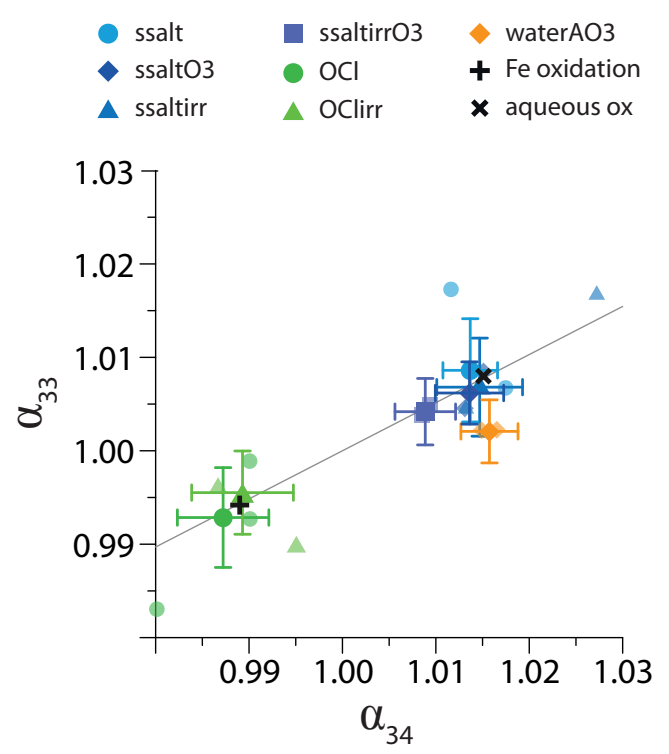

Fig. 5. Fractionation factors for the uptake and oxidation of $\mathrm{SO}_{2}$ by droplets of pure water, sea salt aerosol and $\mathrm{NaOCl}$ aerosol (abbreviations are defined in Table 1). Pale points are the individual experimental runs for each set of conditions, while dark points show the average with $1 \sigma$ error bars. The grey line represents mass dependent fractionation and the black crosses show previously measured fractionation factors from Harris et al. (2012b).

by Laskin et al. (2003); the effect of this pathway is expected to be more significant in the laboratory than in the ambient environment due to the absence of methane and acids such as $\mathrm{HNO}_{3}$ (Keene and Pszenny, 2004; von Glasow, 2006). The uptake coefficient for water $\mathrm{AO}_{3}$ is $0.13 \pm 0.14$, thus it is not significantly different from $\mathrm{ssaltO}_{3}$, however the error in the estimate for waterAO3 is high as the absolute amount of sulfate and the aerosol number concentration are both low, leading to high measurement errors for both parameters.

\subsection{Fractionation of sulfur isotopes during uptake and oxidation in droplets}

In all droplet experiments, $<3 \%$ of $\mathrm{SO}_{2}$ reacted to form sulfate, therefore the isotopic composition of the product sulfate can be directly taken as the $\alpha_{34}$ as Rayleigh fractionation effects due to depletion of the reservoir are insignificant (see Mariotti et al., 1981; Krouse and Grinenko, 1991). The measured fractionation factors are shown in Table 4 and Fig. 5. Irradiation and ozone did not cause significant changes in the measured fractionation factors: The fractionation factors under all experimental conditions for the two different droplet types ( $\mathrm{NaOCl}$ and sea salt aerosols) agree within the measurement error, and the total average $\alpha_{34}$ values for the two droplet types are also shown in Table 4. Fractionation of ${ }^{33} \mathrm{~S} /{ }^{32} \mathrm{~S}$ was mass-dependent with respect to ${ }^{34} \mathrm{~S} /{ }^{32} \mathrm{~S}$ for all experiments.
The $\alpha_{34}$ for waterAO3 $\left(\alpha_{34}=1.0157 \pm 0.0031\right)$ agreed with the value for $\mathrm{H}_{2} \mathrm{O}_{2}$ oxidation under $\mathrm{pH}$ $=2$ from Sect. $3.2\left(\alpha_{34}=1.0154 \pm 0.0037\right)$ and with previous measurements of oxidation by $\mathrm{O}_{3}$ in water $\left(\alpha_{34}=1.0174 \pm 0.0028\right.$; Harris et al., 2012b), confirming that microphysical effects of droplet vs. bulk do not effect fractionation, and that the terminating oxidation for aqueous oxidation by $\mathrm{O}_{3}$ and $\mathrm{H}_{2} \mathrm{O}_{2}$ oxidation is unimportant compared to the phase change and aqueous $\mathrm{S}(\mathrm{IV})$ equilibria (Harris et al., 2012b). An overall $\alpha_{34}$ of $1.0163 \pm 0.0018$ for oxidation by $\mathrm{O}_{3}$ in water was calculated as a weighted average from this study and the previous value. This average represents oxidation at low $\mathrm{pH}$ even in non-buffered solutions, because although $\mathrm{O}_{3}$ reacts several orders of magnitude faster with $\mathrm{SO}_{3}^{2-}$ than with $\mathrm{HSO}_{3}^{-}$, sulfate production will quickly acidify water until the $\mathrm{pH}$ is low enough for the $\left[\mathrm{SO}_{3}^{2-}\right]$ to be negligible.

The fractionation factor for oxidation in $\mathrm{NaOCl}$ solution will represent oxidation by $\mathrm{HOCl}$, as the $\mathrm{pK}_{a}$ of $\mathrm{HOCl}$ is 7.53 so the $\left[\mathrm{OCl}^{-}\right]$will be negligible in acidic solution, and the rate constant for oxidation of sulfite by $\mathrm{HOCl}$ is $>4$ orders of magnitude higher than for $\mathrm{OCl}^{-}$(Yiin and Margerum, 1988; Shaka et al., 2007). The measured value of $\alpha_{34}(0.9882 \pm 0.0036)$ is not significantly different from oxidation by a radical chain reaction initiated by $\mathrm{Fe}(\mathrm{III})$ $\left(\alpha_{34}=0.9905 \pm 0.0031\right.$; Harris et al., 2012a), although the mechanisms are not similar. This suggests that following the equilibrium fractionation of $(17.3 \pm 3.7) \%$ o $\left(\alpha_{34}=\right.$ $1.0173 \pm 0.0037$; from $\mathrm{pH}$-dependent experiments, as shown in Fig. 3) for $\mathrm{SO}_{2}(\mathrm{~g}) \rightleftharpoons \mathrm{HSO}_{3}^{-}$at $19^{\circ} \mathrm{C}$, kinetic effects related to fundamental differences in the energy and stability of sulfite and sulfate - which are common to both reactions - cause kinetic fractionation of $-28 \%$ o $\left(\alpha_{34}=0.972\right)$.

The fractionation factor for oxidation in sea salt aerosol $\left(\alpha_{34}=1.0124 \pm 0.0017\right)$ is lower than the fractionation factor for aqueous oxidation of $\mathrm{SO}_{3}^{2-}\left(\alpha_{34}=1.0225 \pm 0.0044\right)$, although the high $\mathrm{pH}$ and ionic strength of sea water mean $\mathrm{SO}_{3}^{2-}$ would be the dominant species oxidised by $\mathrm{O}_{3}$ or $\mathrm{Cl}$ catalysis, thus showing the role of oxidation by $\mathrm{HOCl}$ in sea salt aerosol. Transition metal ions capable of catalysing oxidation (e.g. Fe, Mn, V; Herrmann et al., 2000; Rani et al., 1992) were not added to the synthetic sea salt mixture, so the contribution of $\mathrm{HOCl}$ oxidation to the total oxidation in sea salt aerosol can be estimated by comparing the overall fractionation in sea salt aerosol to fractionation factors for $\mathrm{SO}_{2}(\mathrm{~g}) \rightarrow \mathrm{SO}_{3}^{2-}$ and oxidation by HOCl. Isotopic mass balance shows that $\mathrm{HOCl}$ contributes $(29 \pm 9) \%$ of oxidation in sea salt aerosol under the conditions of this study. The measured $\alpha_{34}$ in sea salt aerosol is lowest for ssaltirrO3, although the difference between the fractionation factors for ssaltirrO3 and ssaltO3 is within the experimental error. The ssaltirrO3 sample would be expected to have the highest concentration of hypochlorous acid from interface reactions whereby photolysis of $\mathrm{O}_{3}$ leads to formation of $\cdot \mathrm{OH}$ radicals and subsequently $\mathrm{HOCl}$ (see Oum et al. (1998); Knipping et al. (2000) 
for details). The measured $\alpha_{34}$ for ssaltirrO3 shows $\mathrm{HOCl}$ contributed $(40 \pm 16) \%$ of oxidation in this experiment: an increase of $11 \%$ due to photolytic production of $\mathrm{HOCl}$ via $\mathrm{O}_{3}$.

The calculated contributions of the $\mathrm{HOCl}$ pathway are expected to be a minimum compared to the actual atmospheric proportion as $\mathrm{HOCl}$ oxidation is not $\mathrm{pH}$ limited, thus although it contributes only $29 \%$ of oxidation in the short timescale of this study it could become the major oxidation pathway over the lifetime of sea salt aerosol in the marine environment (von Glasow et al., 2002). Although the partitioning between oxidation mechanisms in this study will not be representative of the marine environment due to the complex relationship between oxidation pathways and alkalinity, light, droplet size, and reactant concentrations, the results show that sulfur isotopes are very useful to investigate relative contributions of these oxidation pathways.

\subsection{Comparison to field observations}

A number of studies have used oxygen and sulfur stable isotopes to investigate sources and oxidation pathways of sulfate in the marine boundary layer (MBL). Many of these studies have employed a three-source mixing scheme, explaining sulfur isotope observations with mixing between ${ }^{34} \mathrm{~S}$-enriched sea salt sulfate and marine biogenic $n s s$-sulfate, and a ${ }^{34} \mathrm{~S}$-depleted source that is attributed to anthropogenic or continental sulfate (Patris et al., 2000; Wadleigh, 2004; Turekian et al., 2001). The general success of this mixing model suggests isotopic fractionation has overall only a small effect on measured $\delta^{34} \mathrm{~S}$ of $n s s$-sulfate, thus it is likely the amount of sulfate produced by ${ }^{34} \mathrm{~S}$-enriching, alkalinity limited pathways $\left(\mathrm{O}_{3}\right.$ oxidation and $\mathrm{Cl}$-catalysis $)$ is roughly equal to that from ${ }^{34} \mathrm{~S}$-depleting pathways (Fecatalysis and hypohalite oxidation). Approximately $70 \%$ of $\mathrm{SO}_{2}$ is oxidised to sulfate in the marine boundary layer, thus using the Rayleigh laws, the isotopic effect of oxidation could be a change of between $-6.1 \%$ and $10.1 \%$ (for $100 \%$ of oxidation occurring via the alkalinity non-limited and the alkalinity-limited pathways respectively). To achieve a net fractionation of $0 \%, 57 \%$ of $\mathrm{SO}_{2}$ would need to be oxidised by the alkalinity non-limited pathways, transitionmetal catalysed and hypohalite oxidation.

Field measurements of $\delta^{34} \mathrm{~S}$ in marine environments are often lower than expected and many even fall below the three-source mixing region, while measurements for this regime are rarely enriched in ${ }^{34} \mathrm{~S}$ compared to the threesource mixing region (Wadleigh, 2004). In some samples an isotopically-light "continental" influence was seen although the back trajectories showed a pure marine origin of the air mass (Patris et al., 2000). $\delta^{34} S$ of $n s s$-sulfate is lower in smaller particles, which has been attributed to a larger continental influence in these particles (Turekian et al., 2001; Patris et al., 2000, 2007). These observations could all be explained by the influence of oxidation pathway on isotopic composition. It appears that under some atmospheric conditions the $\mathrm{HOCl} / \mathrm{Fe}$ pathways are favoured over the $\mathrm{O}_{3} / \mathrm{Cl}-$ catalysis pathways, leading to sulfate more depleted in ${ }^{34} \mathrm{~S}$. This may be when alkalinity is low due to low winds, or when aerosols have a longer lifetime to accumulate nsssulfate after alkalinity has been depleted. Alkalinity is depleted in smaller aerosols faster than in larger aerosols, thus the partioning between the alkalinity-limited pathways and $\mathrm{HOCl} / \mathrm{Fe}$ oxidation could account for the lower $\delta^{34} \mathrm{~S}$ values observed in smaller particles.

The triple oxygen isotope composition of sulfate, represented by $\Delta^{17} \mathrm{O}$, has also been used to investigate oxidation pathways of $\mathrm{SO}_{2}$ in the marine environment (Alexander et al., 2005; Patris et al., 2007). $\mathrm{OH}$ radicals and $\mathrm{O}_{2}$, which acts as the oxidant during transition metal catalysis, result in sulfate with $\Delta^{17} \mathrm{O}=0 \%$, while oxidation by $\mathrm{O}_{3}$ and $\mathrm{H}_{2} \mathrm{O}_{2}$ produces sulfate with $\Delta^{17} \mathrm{O}=8.8$ and $0.8 \%$ respectively (Savarino et al., 2000; Lee and Thiemens, 2001). The $\Delta{ }^{17} \mathrm{O}$ of $\mathrm{HO}_{\mathrm{x}}$ has not been measured, however Patris et al. (2007) have estimated it based on the major formation pathways: $\mathrm{HO}_{\mathrm{x}}$ may have a $\Delta^{17} \mathrm{O}$ similar to ozone due to formation from $\mathrm{XNO}_{3}$, or it may have a $\Delta^{17} \mathrm{O}$ of $0 \%$ o if the $\mathrm{HO}_{\mathrm{x}}$ oxygen atom comes from atmospheric water. The $\Delta \Delta^{17} \mathrm{O}$ of $\mathrm{HO}_{\mathrm{x}}$ is only relevant if the $\mathrm{O}$ atom is transferred to sulfate during oxidation. The results of Yiin and Margerum (1988) suggest that the $\mathrm{O}$ atom is added to sulfate from atmospheric water during hydrolysis of chlorosulfuric acid, thus the sulfate formed would have a $\Delta^{17} \mathrm{O}$ of $0 \%$. However this has not been conclusively shown, for example, with an experiment involving isotopically-labelled $\mathrm{HO}_{\mathrm{x}}$. If the $\Delta^{17} \mathrm{O}$ of sulfate produced from hypohalite oxidation was reliably known, it would be possible to distinguish between all the major MBL $\mathrm{SO}_{2}$ oxidation pathways (gas-phase by $\mathrm{OH}$, heterogeneous by $\mathrm{O}_{3}, \mathrm{Cl}$ catalysis, $\mathrm{Fe}$ catalysis and hypohalites) based on the oxygen and sulfur isotopic composition of $\mathrm{SO}_{2}$ and sulfate.

\section{Conclusions}

Sulfur isotope fractionation factors for the oxidation of $\mathrm{SO}_{2}$ in water, synthetic sea water and concentrated $\mathrm{NaOCl}$ droplets were measured. A summary of the measured isotopic fractionation factors in the marine boundary layer is shown in Fig. 6. The fractionation factors for each step from $\mathrm{SO}_{2}\left(\mathrm{~g}\right.$ ) uptake to $\mathrm{SO}_{3}^{2-}$ (aq) formation were measured, showing an increase in isotopic fractionation at higher $\mathrm{pH}$.

Reactive uptake coefficients for $\mathrm{NaOCl}$ droplets were very high, in agreement with the rapid rate of the reaction, while $\gamma_{\text {obs }}$ for sea water reflected alkalinity limitations for oxidation by $\mathrm{O}_{3}$ and $\mathrm{Cl}$ catalysis. $\alpha_{34}$ for oxidation by $\mathrm{O}_{3}$ in water droplets agreed with previous results for aqueous oxidation by $\mathrm{O}_{3}$ and with low $\mathrm{pH}$ measurements, while $\alpha_{34}$ for oxidation by $\mathrm{O}_{3}$ in sea salt aerosol also favoured the heavy isotope but with a lower magnitude. Oxidation in $\mathrm{NaOCl}$ droplets, 


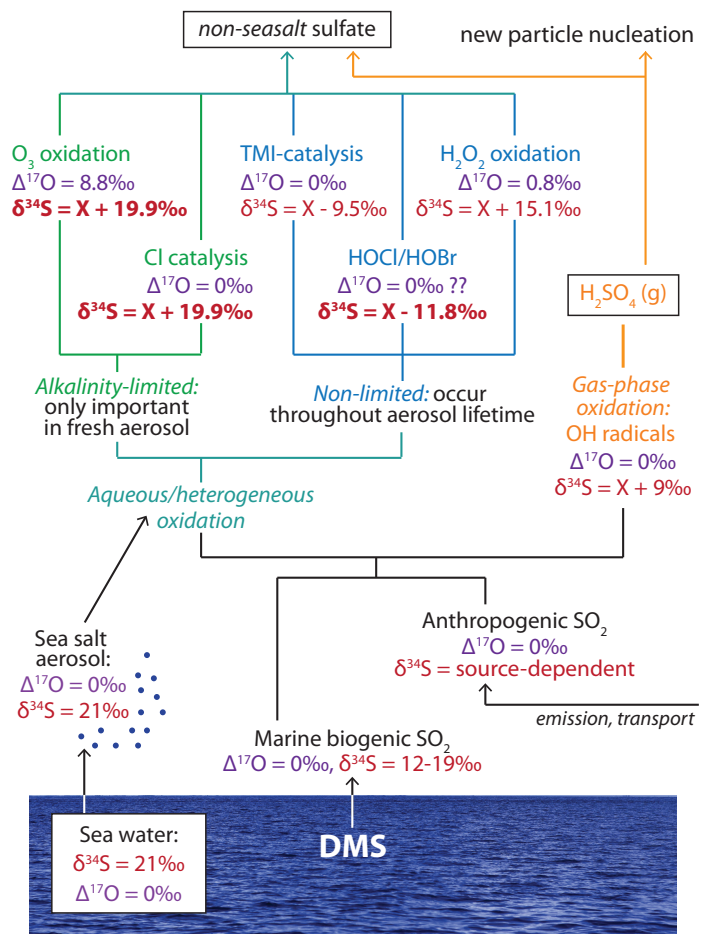

Fig. 6. Summary of the $\mathrm{SO}_{2}$ oxidation reactions occurring in the marine boundary layer and their effect on the isotopic composition of product sulfate. Initial isotopic compositions of sea water and marine biogenic sulfate are from Rees et al. (1978) and Calhoun et al. (1991) respectively. $\Delta^{17} \mathrm{O}$ values refer to the sulfate resulting from oxidation, not the oxidant itself, and are from Savarino et al. (2000). $\delta^{34} \mathrm{~S}$ fractionations during oxidation reactions are shown as a change, where $\mathrm{X}$ is the $\delta^{34} \mathrm{~S}$ of the $\mathrm{SO}_{2}$ reactant gas. Fractionation factors are for $19^{\circ} \mathrm{C}$; those measured in this study are shown in bold and all other ${ }^{34} \mathrm{~S} /{ }^{32} \mathrm{~S}$ fractionations are from Harris et al. (2012b,a).

on the other hand, favoured the light isotope and produced isotopic fractionation indistinguishable from previous measurements for oxidation by iron catalysis. Comparison of the fractionation factors showed that the $\mathrm{HOCl}$ pathway contributed $29 \%$ of oxidation on sea salt aerosol in the short experimental timescale, suggesting that it can play an important role in the marine sulfur cycle. The opposite directions of isotopic fractionation mean that sulfur isotope measurements will be particularly useful to estimate the importance of $\mathrm{SO}_{2}$ oxidation by alkalinity non-limited $\mathrm{HOCl}$ and iron catalysis pathways compared to alkalinity-limited pathways of oxidation, as they favour the light and the heavy sulfur isotopes respectively. Combined measurements of the sulfur isotope composition of both initial $\mathrm{SO}_{2}$ and product sulfate and measurements of $\Delta^{17} \mathrm{O}$ of sulfate may have the potential to distinguish between all the $\mathrm{SO}_{2}$ oxidation pathways occurring in the marine environment. This would allow direct measurements of oxidation in the marine sulfur cycle leading to a new understanding of its role in atmospheric chemistry and climate.
Acknowledgements. We thank Elmar Gröner for his support with the NanoSIMS analyses, John Crowley for valuable discussions on the material presented in this paper, Joachim Huth for his help with the SEM/EDX analyses, and Thomas Klimach for assistance with particle size distribution measurements. We also thank Jan Kaiser, Ann-Lise Norman, Shuhei Ono and the anonymous reviewer for their helpful comments on the paper. This research was funded by the Max Planck Society and the Max Planck Graduate Centre.

The service charges for this open access publication have been covered by the Max Planck Society.

Edited by: J. Kaiser

\section{References}

Alexander, B., Park, R. J., Jacob, D. J., Li, Q. B., Yantosca, R. M., Savarino, J., Lee, C. C. W., and Thiemens, M. H.: Sulfate formation in sea-salt aerosols: Constraints from oxygen isotopes, J. Geophys. Res.-Atmos., 110, D10307, doi:10.1029/2004JD005659, 2005.

Caffrey, P., Hoppel, W., Frick, G., Fitzgerald, J., Shantz, N., Leaitch, W. R., Pasternack, L., Albrechcinski, T., and Ambrusko, J.: Chamber measurements of CI depletion in cloud-processed sea-salt aerosol, J. Geophys. Res.-Atmos., 106, 27635-27645, doi:10.1029/2000JD000105, 2001.

Calhoun, J. A., Bates, T. S., and Charlson, R. J.: Sulfur Isotope Measurements of Submicrometer Sulfate Aerosol-Particles over the Pacific-Ocean, Geophys. Res. Lett., 18, 1877-1880, 1991.

Chameides, W. L. and Stelson, A. W.: Aqueous-Phase Chemical Processes in Deliquescent Sea-Salt Aerosols: A Mechanism That Couples the Atmospheric Cycles of S and Sea Salt, J. Geophys. Res., 97, 20565-20580, 1992.

Chmielewski, A. G., Derda, M., Wierzchnicki, R., and Mikolajczuk, A.: Sulfur isotope effects for the $\mathrm{SO}_{2}(\mathrm{~g})-\mathrm{SO}_{2}(\mathrm{aq})$ system, Nukleonika, 47, S69-S70, 2002.

Ding, T., Valkiers, S., Kipphardt, H., De Bievre, P., Taylor, P. D. P., Gonfiantini, R., and Krouse, R.: Calibrated sulfur isotope abundance ratios of three IAEA sulfur isotope reference materials and V-CDT with a reassessment of the atomic weight of sulfur, Geochim. Cosmochim. Ac., 65, 2433-2437, 2001.

Egiazarov, A. C., Kaviladze, M., Kerner, M. N., Oziashvili, E. L., Ebralidze, A., and Esakiya, A. D.: Separation of Sulfur Isotopes by Chemical Exchange, Isotopenpraxis, Isot. Environ. Healt. S., 7, 379-383, 1971.

Eriksen, T. E.: Sulfur Isotope Effects 1. Isotopic Exchange Coefficient for Sulfur Isotopes 34S-32S in System $\mathrm{SO}_{2}(\mathrm{~g})-\mathrm{HSO}_{3}(\mathrm{aq})$ at 25, 35, and 45 Degrees C, Acta Chem. Scand., 26, 573-580, 1972.

Fogelman, K. D., Walker, D. M., and Magerum, D. W.: Non-metal Redox Kinetics - Hypochlorite and Hypochlorous Acid Reactions With Sulfite, Inorg. Chem., 28, 986-993, doi:10.1021/ic00305a002, 1989.

Gebel, M. E., Finlayson, Pitts, B. J., and Ganske, J. A.: The uptake of SO2 on synthetic sea salt and some of its components, Geophys. Res. Lett., 27, 887-890, 2000.

Groener, E. and Hoppe, P.: Automated ion imaging with the NanoSIMS ion microprobe, Appl. Surf. Sci., 252, 7148-7151, doi:10.1016/j.apsusc.2006.02.280, 2006. 
Gurciullo, C., Lerner, B., Sievering, H., and Pandis, S. N.: Heterogeneous sulfate production in the remote marine environment: Cloud processing and sea-salt particle contributions, J. Geophys. Res., 104, 21719-21731, 1999.

Harris, E., Sinha, B., Foley, S., Crowley, J. N., Borrmann, S., and Hoppe, P.: Sulfur isotope fractionation during heterogeneous oxidation of $\mathrm{SO}_{2}$ on mineral dust, Atmos. Chem. Phys. Discuss., 12, 2303-2353, doi:10.5194/acpd-12-2303-2012, 2012a.

Harris, E., Sinha, B., Hoppe, P., Crowley, J. N., Ono, S., and Foley, S.: Sulfur isotope fractionation during oxidation of sulfur dioxide: Gas-phase oxidation by $\mathrm{OH}$ radicals and aqueous oxidation by $\mathrm{H}_{2} \mathrm{O} 2, \mathrm{O}_{3}$ and iron catalysis, Atmos. Chem. Phys., 12, 407423, doi:10.5194/acp-12-407-2012, 2012b.

Herrmann, H., Ervens, B., Jacobi, H. W., Wolke, R., Nowacki, P., and Zellner, R.: CAPRAM2.3: A chemical aqueous phase radical mechanism for tropospheric chemistry, J. Atmos. Chem., 36, 231-284, 2000.

Hoppe, P.: NanoSIMS: A new tool in cosmochemistry, Appl. Surf. Sci., 252, 7102-7106, 2006.

Hoppel, W. A. and Caffrey, P. F.: Oxidation of S(IV) in sea-salt aerosol at high pH: Ozone versus aerobic reaction, J. Geophys. Res.-Atmos., 110, D23202, doi:10.1029/2005JD006239, 2005.

Hoppel, W., Pasternack, L., Caffrey, P., Frick, G., Fitzgerald, J., Hegg, D., Gao, S., Ambrusko, J., and Albrechcinski, T.: Sulfur dioxide uptake and oxidation in sea-salt aerosol, J. Geophys. Res.-Atmos., 106, 27575-27585, doi:10.1029/2000JD900843, 2001.

IUPAC: Data Sheet VI.A2.8, http://www.iupac-kinetic.ch.cam.ac. uk, 2009.

Jayne, J. T., Davidovits, P., Worsnop, D. R., Zahniser, M. S., and Kolb, C. E.: Uptake of SO2(g) By Aqueous Surfaces As A Function of $\mathrm{pH}$ - the Effect of Chemical-reaction At the Interface, J. Phys. Chem.-US, 94, 6041-6048, doi:10.1021/j100378a076, 1990.

Katoshevski, D., Nenes, A., and Seinfeld, J. H.: A study of processes that govern the maintenance of aerosols in the marine boundary layer, J. Aerosol. Sci., 30, 503-532, doi:10.1016/S0021-8502(98)00740-X, 1999.

Keene, W. C. and Pszenny, A. A. P.: Comment on "Reactions at interfaces as a source of sulfate formation in sea-salt particles" (I), Science, 303, p. 628b, 2004.

Kester, D. R., Duedall, I. W., Connors, D. N., and Pytkowic, R.: Preparation of Artificial Seawater, Limnol. Oceanogr., 12, 176179, 1967.

Knipping, E. M., Lakin, M. J., Foster, K. L., Jungwirth, P., Tobias, D. J., Gerber, R. B., Dabdub, D., and Finlayson-Pitts, B. J.: Experiments and simulations of ion-enhanced interfacial chemistry on aqueous $\mathrm{NaCl}$ aerosols, Science, 288, 301-306, 2000.

Krouse, H. R. and Grinenko, V. A.: Stable isotopes : natural and anthropogenic sulphur in the environment, 43, Wiley, Chichester, UK, 1991.

Krouse, H., Grinenko, L., Grinenko, V., Newman, L., Forrest, J., Nakai, N., Tsuji, Y., Yatsumimi, T., Takeuchi, V., Robinson, B., Stewart, M., Gunatilaka, A., Plumb, L., Smith, J., Buzek, F., Cerny, J., Sramek, J., Menon, A., Iyer, G., Venkatasubramanian, V., Egboka, B., Irogbenachi, M., and Eligwe, C.: Stable Isotopes: Natural and Anthropogenic Sulphur in the Environment, chap. 8. Case Studies and Potential Applications, 307-416, John Wiley and Sons, 1991.
Laskin, A., Gaspar, D. J., Wang, W. H., Hunt, S. W., Cowin, J. P., Colson, S. D., and Finlayson-Pitts, B. J.: Reactions at interfaces as a source of sulfate formation in sea-salt particles, Science, 301, 340-344, 2003.

Lee, C. C. W. and Thiemens, M. H.: The delta O-17 and delta O18 measurements of atmospheric sulfate from a coastal and high alpine region: A mass-independent isotopic anomaly, J. Geophys. Res.-Atmos., 106, 17359-17373, 2001.

Mariotti, A., Germon, J. C., Hubert, P., Kaiser, P., Letolle, R., Tardieux, A., and Tardieux, P.: Experimental-determination of Nitrogen Kinetic Isotope Fractionation - Some Principles - Illustration For the Denitrification and Nitrification Processes, Plant Soil, 62, 413-430, 1981.

Millero, F. J.: Physical-chemistry of Seawater, Annu. Rev. Earth Pl. Sc., 2, 101-150, 1974.

Moore, J., Stanitski, C., and Jurs, P.: Chemistry: The Molecular Science, Brooks/Cole - Thomson Learning, USA, 2005.

Nielsen, H., Pilot, J., Grinenko, L., Grinenko, V., Lein, A., Smith, J., and Pankina, R.: Stable Isotopes: Natural and Anthropogenic Sulphur in the Environment, chap. 4., Lithospheric Sources of Sulfur, 65-132, John Wiley and Sons, 1991.

Oum, K. W., Lakin, M. J., DeHaan, D. O., Brauers, T., and Finlayson-Pitts, B. J.: Formation of molecular chlorine from the photolysis of ozone and aqueous sea-salt particles, Science, 279, 74-77, 1998.

Patris, N., Mihalopoulos, N., Baboukas, E. D., and Jouzel, J.: Isotopic composition of sulfur in Size-resolved marine aerosols above the Atlantic Ocean., J. Geophys. Res.-Atmos., 105, 14449-14457, 2000.

Patris, N., Cliff, S. S., Quinn, P. K., Kasem, M., and Thiemens, M. H.: Isotopic analysis of aerosol sulfate and nitrate during ITCT-2k2: Determination of different formation pathways as a function of particle size, J. Geophys. Res.-Atmos., 112, D23301, doi:10.1029/2005JD006214, 2007.

Rani, A., Prasad, D. S. N., Madnawat, P. V. S., and Gupta, K. S.: The Role of Free-fall Atmospheric Dust In Catalyzing Autoxidation of Aqueous Sulfur-dioxide, Atmos. Environ. A-Gen., 26, 667673, 1992.

Rees, C. E., Jenkins, W. J., and Monster, J.: Sulfur Isotopic Composition of Ocean Water Sulfate, Geochim. Cosmochim. Ac., 42, 377-381, 1978.

Sander, R. and Crutzen, P. J.: Model study indicating halogen activation and ozone destruction in polluted air masses transported to the sea, J. Geophys. Res., 101, 9121-9138, doi:10.1029/95JD03793, 1996.

Sander, R., Crutzen, P. J., and von Glasow, R.: Comment on "Reactions at interfaces as a source of sulfate formation in sea-salt particles" (II), Science, 303, p. 628c, 2004.

Sanusi, A. A., Norman, A.-L., Burridge, C., Wadleigh, M., and Tang, W.-W.: Determination of the S isotope composition of methanesulfonic acid, Anal. Chem., 78, 4964-4968, doi:10.1021/ac0600048, 2006.

Savarino, J., Lee, C. C. W., and Thiemens, M. H.: Laboratory oxygen isotopic study of sulfur (IV) oxidation: Origin of the massindependent oxygen isotopic anomaly in atmospheric sulfates and sulfate mineral deposits on Earth, J. Geophys. Res.-Atmos., 105, 29079-29088, 2000.

Shaka, H., Robertson, W. H., and Finlayson-Pitts, B. J.: A new approach to studying aqueous reactions using diffuse reflectance in- 
frared Fourier transform spectrometry: application to the uptake and oxidation of SO2 on OH-processed model sea salt aerosol, Phys. Chem. Chem. Phys., 9, 1980-1990, 2007.

Sievering, H., Boatman, J., Galloway, J., Keene, W., Kim, Y., Luria, M., and Ray, J.: Heterogeneous Sulfur Conversion In Sea-salt Aerosol Particles - the Role of Aerosol Water Content and Size Distribution, Atmos. Environ. A-Gen., 25, 1479-1487, 1991.

Sievering, H., Gorman, E., Ley, T., Pszenny, A., Springer-Young, M., Boatman, J., Kim, Y., Nagamoto, C., and Wellman, D.: Ozone oxidation of sulfur in sea-salt aerosol particles during the Azores Marine Aerosol and Gas Exchange experiment, J. Geophys. Res., 100, 23075-23081, 1995.

Sievering, H., Lerner, B., Slavich, J., Anderson, J., Posfai, M., and Cainey, J.: O3 oxidation of SO2 in sea-salt aerosol water: Size distribution of non-sea-salt sulfate during the First Aerosol Characterization Experiment (ACE 1), J. Geophys. Res., 104, 2170721717, 1999.

Sievering, H., Cainey, J., Harvey, M., McGregor, J., Nichol, S., and Quinn, P.: Aerosol non-sea-salt sulfate in the remote marine boundary layer under clear-sky and normal cloudiness conditions: Ocean-derived biogenic alkalinity enhances sea-salt sulfate production by ozone oxidation, J. Geophys. Res., 109, D19317, doi:10.1029/2003JD004315, 2004.

Troy, R. C. and Margerum, D. W.: Nonmetal Redox Kinetics - Hypobromite and Hypobromous Acid Reactions With Iodide and With Sulfite and the Hydrolysis of Bromosulfate, Inorg. Chem., 30, 3538-3543, doi:10.1021/ic00018a028, 1991.

Turekian, V. C., Macko, S. A., and Keene, W. C.: Application of stable sulfur isotopes to differentiate sources of size-resolved particulate sulfate in polluted marine air at Bermuda during spring, Geophys. Res. Lett., 28, 1491-1494, 2001. van Loon, G. and Duffy, S.: Environmental Chemistry: A Global Perspective, Oxford University Press, 1-492, 2000.

von Glasow, R. and Crutzen, P. J.: Model study of multiphase DMS oxidation with a focus on halogens, Atmos. Chem. Phys., 4, 589608, doi:10.5194/acp-4-589-2004, 2004.

von Glasow, R. and Sander, R.: Variation of sea salt aerosol pH with relative humidity, Geophys. Res. Lett., 28, 247-250, 2001.

von Glasow, R.: Importance of the surface reaction $\mathrm{OH}+\mathrm{Cl}^{-}$ on sea salt aerosol for the chemistry of the marine boundary layer - a model study, Atmos. Chem. Phys., 6, 3571-3581, doi:10.5194/acp-6-3571-2006, 2006.

von Glasow, R., Sander, R., Bott, A., and Crutzen, P. J.: Modeling halogen chemistry in the marine boundary layer -2 . Interactions with sulfur and the cloud-covered MBL, J. Geophys. Res.Atmos., 107, 4323, doi:10.1029/2001JD000943, 2002.

Wadleigh, M. A.: Sulphur isotopic composition of aerosols over the western North Atlantic Ocean, Can. J. Fish Aquat. Sci., 61, 817825, doi:10.1139/f04-073, 2004.

Winterholler, B., Hoppe, P., Andreae, M. O., and Foley, S.: Measurement of sulfur isotope ratios in micrometer-sized samples by NanoSIMS, Appl. Surf. Sci., 252, 7128-7131, 2006.

Winterholler, B., Hoppe, P., Foley, S., and Andreae, M. O.: Sulfur isotope ratio measurements of individual sulfate particles by NanoSIMS, Int. J. Mass. Spectrom., 272, 63-77, 2008.

Yiin, B. S. and Margerum, D. W.: Kinetics of Hydrolysis of the Chlorosulfate Ion, Inorg. Chem., 27, 1670-1672, doi:10.1021/ic00283a002, 1988.

Zhang, J. Z. and Millero, F. J.: The Rate of Sulfite Oxidation In Seawater, Geochim. Cosmochim. Ac., 55, 677-685, doi:10.1016/0016-7037(91)90333-Z, 1991. 